\title{
Greenhouse Gas Emission Mitigation of Large-Scale Wastewater Treatment Plants (WWTPs ): Optimization of Sludge Treatment and Disposal
}

\author{
Gang Zhao ${ }^{1,2}$, Wei Liu ${ }^{2}$, Jingcheng $\mathrm{Xu}^{2 *}$, Xiangfeng Huang², Xiaohu Lin ${ }^{2}$, \\ Juwen Huang', Guangming $\mathbf{L i}^{2}$
}

${ }^{1}$ Shanghai Urban Construction Design \& Research Institute, 3447 Dongfang Rd, Shanghai 200120, PR China ${ }^{2}$ College of Environmental Science \&Engineering, Tongji University, Shanghai 200092, PR China

Received: 13 January 2020

Accepted: 16 March 2020

\begin{abstract}
Wastewater treatment plants (WWTPs) contribute to anthropogenic greenhouse gas (GHG) emissions. Due to the lack of estimation methods and operation data, whole plant characterization of GHG emissions from WWTPs is still unclear. In this study, a set of methods were developed to calculate direct, indirect and avoided GHG generated from large-scale WWTPs in China. The characteristic of GHG emissions from two representative large-scale WWTPs situated in eastern China were investigated. Results showed that the GHG emission of sludge treatment and disposal from two WWTPs accounted for $76 \%$ and $65 \%$ of total emissions, respectively. This study investigated the GHG performance of three typical sludge treatment and disposal routes including land application (R1), incineration (R2) and landfilling (R3). R3 showed the highest GHG emission with $4322 \mathrm{~kg} \mathrm{CO}_{2}$-eq/t dry sludge, followed by $\mathrm{R} 2$ (3124 kg CO 2 -eq/t dry sludge) and $\mathrm{R} 1$ (489 kg CO 2 -eq/t dry sludge). Two energy recovery strategies were evaluated in terms of their impacts on the GHG emissions from R1, R2 and R3. Strategy A and B reduced significantly GHG emission from three routes. R3 exhibited the best performance of GHG reduction with reduction rate of $51 \%$ (strategy A) and $77 \%$ (strategy $\mathrm{B}$ ). The future direction of $\mathrm{CO}_{2}$ emission reduction is to minimize landfill disposal of sludge and to utilize sludge as a source of energy.
\end{abstract}

Keywords: greenhouse gas emission, wastewater treatment plant, energy recovery, sludge treatment and disposal

*e-mail: xujick@tongji.edu.cn 


\section{Introduction}

The increasing greenhouse gas (GHG) emission from anthropogenic activities has been widely considered the main cause of global warming. The treatment of wastewater has been identified as a source of anthropogenic GHG emissions. WWTPs have the potential to produce carbon dioxide $\left(\mathrm{CO}_{2}\right)$, methane $\left(\mathrm{CH}_{4}\right)$ and nitrous oxide $\left(\mathrm{N}_{2} \mathrm{O}\right)$ through several chemical and biological processes as well as energy production and combustion [1-4]. It has been reported that water and wastewater sectors account for about $2.8 \%$ of global GHG emissions [5].

In the 2015 Paris Climate Conference, China pledged to peak its $\mathrm{CO}_{2}$ emissions around the year of 2030 or even more early with continuous efforts. $\mathrm{CO}_{2}$ per unit of GDP will be reduced by $60-65 \%$ of the level in by 2030 . Thus, WWTPs in China will soon confront with the challenges of mitigating their GHG emissions. The quantification methods of GHG emissions from WWTPs should be established, and effective emission control strategies should be put forward as soon as possible.

Several studies adopted methods such as life cycle assessment (LCA), intergovernmental panel on climate change (IPCC) methodology, clean development mechanism (CDM) method and other carbon accounting models to estimate the GHG emission from wastewater and sludge treatment processes [6-9]. However, most of the previous studies investigated the GHG emissions from WWTPs without considering sludge treatment and disposal. Sewage sludge, the byproduct of the wastewater treatment process, has become one of the most significant challenges in WWTPs of China [10]. Although near $80 \%$ of WWTPs in China are equipped with treatment facilities, more than $80 \%$ of sludge is not treated well [11]. GHG emission from sewage sludge treatment and disposal processes is eliciting increasing attention. The handling processes and energy consumption required for sludge management emit considerable amounts of GHG. During the landfilling of sludge, organic fractions are degraded and significant amounts of $\mathrm{CH}_{4}$ were generated. In addition, the nitrogen in sludge could be converted into minor amounts of $\mathrm{N}_{2} \mathrm{O}$ during sludge incineration and land application [12]. About $40 \%$ of GHG in wastewater systems can be attributed to sewage sludge treatment and disposal processes [13]. According to our initial investigation of several large-scale WWTPs of eastern China, the GHG emissions contributed more than $60 \%$ of the plant emissions.

To date, few studies focused on calculating GHG emission from both wastewater treatment and sludge treatment and disposal in China. Moreover, the estimation of GHG from WWTPs usually adapts the default emission factor suggested by IPCC due to the lack of China-specific factors. Evidence indicates that the characteristics of sewage and sludge treatment schemes in China differ from those in developed countries $[11,14]$. Therefore, a case study of WWTPs should be conducted to analyze the characteristic of GHG emission based on actual operation data. Meanwhile, it is important to note that sludge contained lots of renewable organic matters and soil nutrients such as nitrogen and phosphorus, which are considered as energy sources [15]. Therefore, analysis and optimization of GHG emission from typical sludge treatment and disposal routes by energy recovery would be critical for emission reduction of Chinese WWTPs.

This article aims to establish a set of GHG emission calculation methods including wastewater treatment, sludge treatment and disposal. Usually, large-scale WWTPs have well-equipped sludge management facilities, and the research data for calculation were easily obtained. Two large-scale WWTPs were selected to investigate the GHG emission characteristic of the whole plant, and the GHG emission performances of three typical sludge treatment and disposal routes were also discussed. The influences of key energy recovery unit on the reduction of GHG emission were evaluated and two optimized sludge treatment and disposal strategies based on energy recovery were put forward to mitigate GHG emissions.

\section{Methodology}

\section{System Boundary}

The accounting model for a WWTP includes wastewater treatment, sludge treatment and disposal. The GHG emissions comprise direct, indirect and avoided emissions. Direct emissions refer to $\mathrm{CH}_{4}$ and $\mathrm{N}_{2} \mathrm{O}$ emitted from open water surface of each treatment unit, $\mathrm{CH}_{4}$ leakage from anaerobic digesters, $\mathrm{CH}_{4}$ emission from landfill site, $\mathrm{N}_{2} \mathrm{O}$ emission from incineration of sludge, and $\mathrm{N}_{2} \mathrm{O}$ emission from land application unit. The IPCC considers that carbon in wastewater to be biogenic, and thus $\mathrm{CO}_{2}$ emissions from organic matter degradation are excluded from reporting [16]. Indirect emissions refer to $\mathrm{CO}_{2}$ emitted by the production of energy and chemicals consumed during the operation. The avoided GHG emissions are attributed to materials substitution such as fertilizer production avoided by land application of sludge, and energy recovery (energy production avoided by biogas from anaerobic digestion or incineration of sludge) would be calculated.

\section{Calculation Methods}

\section{$\mathrm{N}_{2} \mathrm{O}$ and $\mathrm{CH}_{4}$ Direct Emissions from Wastewater Treatment}

Due to the lack of GHG emission factors in China, the direct GHG emission is recommended to be calculated by field monitoring. A closed chamber 
technique is used to measure fluxes from liquid surfaces. The flux chamber is employed to collect $\mathrm{N}_{2} \mathrm{O}$ and $\mathrm{CH}_{4}$ gas samples at different locations in each wastewater processing unit. The quantity of $\mathrm{N}_{2} \mathrm{O}$ and $\mathrm{CH}_{4}$ emissions was measured and calculated according to the previous research [17].

\section{$\mathrm{CH}_{4}$ Direct Leakage from Anaerobic Digester}

$\mathrm{CH}_{4}$ emissions may include the leakage of methane from the digester and pipelines as well as incomplete combustion of biogas in flaring equipment. The $\mathrm{CH}_{4}$ emission from the digester leakage is determined by the quantity of biogas collected at digester outlet and the fraction of biogas that leaks from the digester. In this study, the value of $0.028 \mathrm{~m}^{3}$ biogas leaked $/ \mathrm{m}^{3}$ biogas produced is considered $\mathrm{CH}_{4}$ emission factor from the digester leakage [18].

\section{$\mathrm{CH}_{4}$ Direct Emission from the Landfill Site}

Assuming that all potential $\mathrm{CH}_{4}$ is released within one year. The $\mathrm{CH}_{4}$ emission from the landfill site can be estimated:

$$
E=M_{l f} * M C F * D O C * D O C_{F} * F_{l f} * \frac{16}{12} * G W P_{C H_{4}}
$$

...where, $E$ is the $\mathrm{CH}_{4}$ emission from decomposition of sludge in the landfill $\left(\mathrm{kg} \mathrm{CO}\right.$-eq); $M_{l f}$ is the quantity of dry sludge ( $\mathrm{kg} \mathrm{DS}) ; M C F$ is the methane conversion factor, which varies with the type of sludge disposal site. The value of $M C F$ is 1 according to IPCC [16]. DOC is degradable organic content in the dry matter of sludge landfilled; $D O C_{F}$ is the fraction of degradable organic content dissimilated to biogas, which is $0.5[16] ; F_{l f}$ is the fraction of methane in the gas, which is 0.5 [16]; 16/12 is the ratio of molar masses of methane and carbon. $G W P_{C H 4}$ is global warming potential of methane and 25 is taken as the value for calculation.

\section{$\mathrm{N}_{2} \mathrm{O}$ Direct Emission from Sludge Land Application and Incineration}

$\mathrm{N}_{2} \mathrm{O}$ is emitted due to the imported nitrogen from sludge through land application and incineration. The amount of $\mathrm{N}_{2} \mathrm{O}$ emission can be determined by the quantity of dried sludge for land use, proportion of nitrogen and $\mathrm{N}_{2} \mathrm{O}$ emission factor for land application and incineration. In this study $1.7 \% \mathrm{~N}_{2} \mathrm{O}$ of initial $\mathrm{N}$ is taken as $\mathrm{N}_{2} \mathrm{O}$ land application emission factor and 0.7 $\mathrm{N}_{2} \mathrm{O}$ of initial $\mathrm{N}$ as $\mathrm{N}_{2} \mathrm{O}$ incineration emission factor $[19,20]$.

\section{Indirect Emissions due to Chemical and Energy Consumption}

The energy and chemical consumption required during the wastewater and sludge treatment process cause indirect $\mathrm{CO}_{2}$ emission, which is determined by the electricity carbon emission factor and chemical emission factor. The emission factor for electricity generation is adopted as $0.8095 \mathrm{~kg} \mathrm{CO}$-eq/kWh [21]. $\mathrm{CO}_{2}$ emission factors for $\mathrm{Al}_{2}\left(\mathrm{SO}_{4}\right)_{3}, \mathrm{PAM}, \mathrm{CaO}$ and $\mathrm{FeCl}_{3}$ are $0.276,2.082,1.264$ and $0.077 \mathrm{~kg} \mathrm{CO} / \mathrm{kg}$, respectively [22].

\section{Avoided $\mathrm{CO}_{2}$ Emission from Biogas Utilization}

The avoided $\mathrm{CO}_{2}$ is attributed to the biogas utilization, which is completed in plants either for electricity or for combined heat and power (CHP) purposes. In a CHP unit, $1 \mathrm{~m}^{3}$ of biogas would produce $1.7 \mathrm{kWh}$ of electricity (35-40\%) and $7.2 \mathrm{MJ}$ of heat $(45-50 \%)$ at $85-90 \%$ conversion efficiency [23]. The electricity generated from biogas recovery is assumed to be equivalent to the same amount of electricity produced by a coal-fired power plant, while the heat generated from biogas recovery is assumed to be equal to the heat generated from coal consumption. Therefore, the avoided $\mathrm{CO}_{2}$ emissions can be estimated by the following equation:

$$
E=-B_{u}\left(1.7 * E F_{\text {ele }}+7.2 * E F_{\text {coal }}\right)
$$

...where, $E$ is the avoided $\mathrm{CO}_{2}$ emission by using biogas ( $\mathrm{kg} \mathrm{CO}$-eq); $B_{u}$ is the quantity of biogas utilized for $\mathrm{CHP}\left(\mathrm{m}^{3}\right) ; E F_{\text {ele }}$ is emission factor for electricity generation ( $\mathrm{kg} \mathrm{CO}$-eq/kWh); $E F_{\text {coal }}$ is $\mathrm{CO}_{2}$ emission factor of diesel $\left(\mathrm{kg} \mathrm{CO}_{2} / \mathrm{MJ}\right)$. The emission factor of coal is $0.23 \mathrm{~kg} \mathrm{CO} / \mathrm{MJ}$ according to IPCC [17].

\section{Avoided $\mathrm{CO}_{2}$ Emission from Sludge Incineration}

During incineration, the heat generated from sludge or auxiliary fuel can be treated as recovered energy. Energy conversion is conducted by electricity recovery only, with a gross electricity conversion efficiency of $17 \%$. The generated electricity is delivered to the national power grid to supplement the electricity produced by conventional fuel. The avoided $\mathrm{CO}_{2}$ emission can be calculated by:

$E=-\frac{M_{\text {inci }} * H_{\text {sludge }}+M_{a u} * H_{a u}}{3.6} * 0.17 * E F_{\text {ele }}$

...where, $E$ is the avoided $\mathrm{CO}_{2}$ emission by energy recovery from incineration process $\left(\mathrm{kg} \mathrm{CO}\right.$-eq); $M_{\text {inci }}$ is the quantity of dried sludge for incineration ( $\mathrm{kg} \mathrm{DS})$; $H_{\text {sludge }}$ is the lower heat value of sludge $(\mathrm{MJ} / \mathrm{kg}) ; M_{a u}$ is the quantity of auxiliary fuel $(\mathrm{kg}) ; H_{a u}$ is the lower heat value of auxiliary fuel $(\mathrm{MJ} / \mathrm{kg}) ; E F_{\text {ele }}$ is $\mathrm{CO}_{2}$ emission factor of electricity $(\mathrm{kg} \mathrm{CO} / \mathrm{kWh})$.

\section{Avoided $\mathrm{CO}_{2}$ Emission from Land Application}

The sludge which contains a certain amount of $\mathrm{N}$ and $\mathrm{P}$ elements for land application can reduce $\mathrm{CO}_{2}$ 
emissions from the production of chemical fertilizers. About $61 \%$ of $\mathrm{N}$ and $70 \%$ of $\mathrm{P}$ (weight ratio) in sludge are available [24]. The emission factor of nitrogen and phosphorus fertilizer production is $5.29 \mathrm{~kg} \mathrm{CO} / \mathrm{kg}$ and $0.51 \mathrm{~kg} \mathrm{CO} / \mathrm{kg}$, respectively [25]. Therefore, the avoided $\mathrm{CO}_{2}$ emission from sludge land application could be calculated by the following equation:

$$
E=-\left(0.61 * S_{N} * 5.29+0.7 * S_{P} * 0.51\right) * M_{l a}
$$

...where, $E$ is the avoided $\mathrm{CO}_{2}$ emission by fertilizer substitution from land application $\left(\mathrm{kg} \mathrm{CO}\right.$-eq); $S_{N}$ is the nitrogen content of sludge $(\mathrm{kg} \mathrm{N} / \mathrm{kg} \mathrm{DS}) ; S_{P}$ is the phosphorus content of sludge ( $\mathrm{kg} \mathrm{P} / \mathrm{kg} \mathrm{DS}) ; M_{l a}$ is the quantity of dried sludge for land use (kg DS).

\section{The Case Study}

Two representative large-scale WWTPs (A-WWTP and B-WWTP) in eastern China are chosen to investigate the GHG emission characteristic in this study. Fig. 1 shows the flow diagram of the major wastewater treatment and sludge disposal processes in these two WWTPs. A-WWTP treats domestic sewage using $\mathrm{A}^{2} \mathrm{O}$ process with a treatment capacity of $200 \times 10^{4} \mathrm{~m}^{3} / \mathrm{d}$. B-WWTP treats domestic sewage using $\mathrm{AO}$ process with a treatment capacity of $40 \times 10^{4} \mathrm{~m}^{3} / \mathrm{d}$. Removal rates of $\mathrm{COD}$ and $\mathrm{TN}$ in A-WWTP and B-WWTP are $90.5 \%$ and $53.1 \%$, and $84 \%$ and $58.4 \%$, respectively. The effluent qualities of the two WWTPs meet the class 2 of Discharge Standard of Pollutants for Municipal Wastewater Treatment Plant GB 18918-2002.

The yearly data of wastewater flow, the amount of sludge with water content, electricity and materials consumed are presented in Fig. 1. According to the calculation methods established, the parameters (Table 1) used for estimating GHG emission from the two large-scale WWTPs are obtained through laboratory analysis.

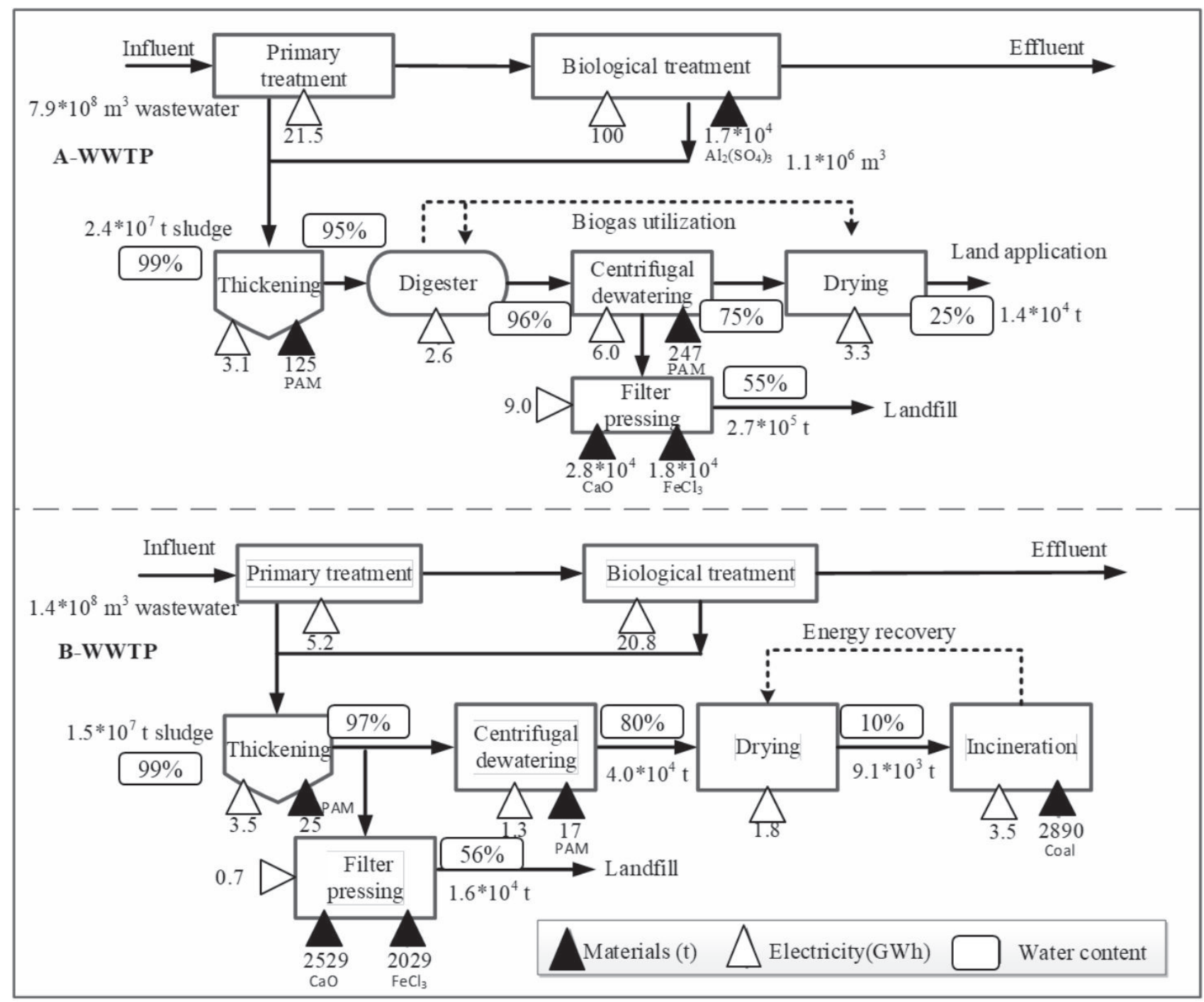

Fig. 1. The flow diagram of the two WWTPs. 
Table 1. Parameters used in the GHG calculation of A-WWTP and B-WWTP.

\begin{tabular}{|c|c|c|c|}
\hline Parameter & Definition & Data & Unit \\
\hline \multicolumn{4}{|c|}{ Sludge properties of A-WWTP } \\
\hline$D O C$ & Degradable organic content of sludge landfilled & 0.34 & $\mathrm{~kg} / \mathrm{kg}$ \\
\hline$S_{N}$ & Nitrogen content of sludge for land use & 0.04 & $\mathrm{~kg} / \mathrm{kg}$ \\
\hline$S_{P}$ & Phosphorus content of sludge for land use & 0.015 & $\mathrm{~kg} / \mathrm{kg}$ \\
\hline \multicolumn{4}{|c|}{ Sludge properties of B-WWTP } \\
\hline$D O C$ & Degradable organic content of sludge landfilled & 0.41 & $\mathrm{~kg} / \mathrm{kg}$ \\
\hline$L_{N}$ & Nitrogen content of sludge for incineration & 0.038 & $\mathrm{~kg} / \mathrm{kg}$ \\
\hline$H_{\text {sludge }}$ & The lower heat value of sludge & 11.5 & $\mathrm{MJ} / \mathrm{kg}$ \\
\hline
\end{tabular}

\section{Results and Discussion}

General Results

The distribution of net GHG emissions from A-WWTP and B-WWTP are shown in Fig. 2. For both WTTPs, sludge disposal is the major $\mathrm{CO}_{2}$ emissions source, and this amounts to $65 \%$ and $54 \%$ of total
GHG emissions respectively, because most of sludge is disposed by landfilling. The GHG emissions from wastewater biological treatment unit and sludge filter presing unit are the second and the third highest, respectively. The sludge treatment makes up a small fraction ( $11 \%$ of the total), which is mainly attributed to utilization of biogas produced from anaerobic digestion unit (Fig. 2a). Therefore, the proportion of GHG

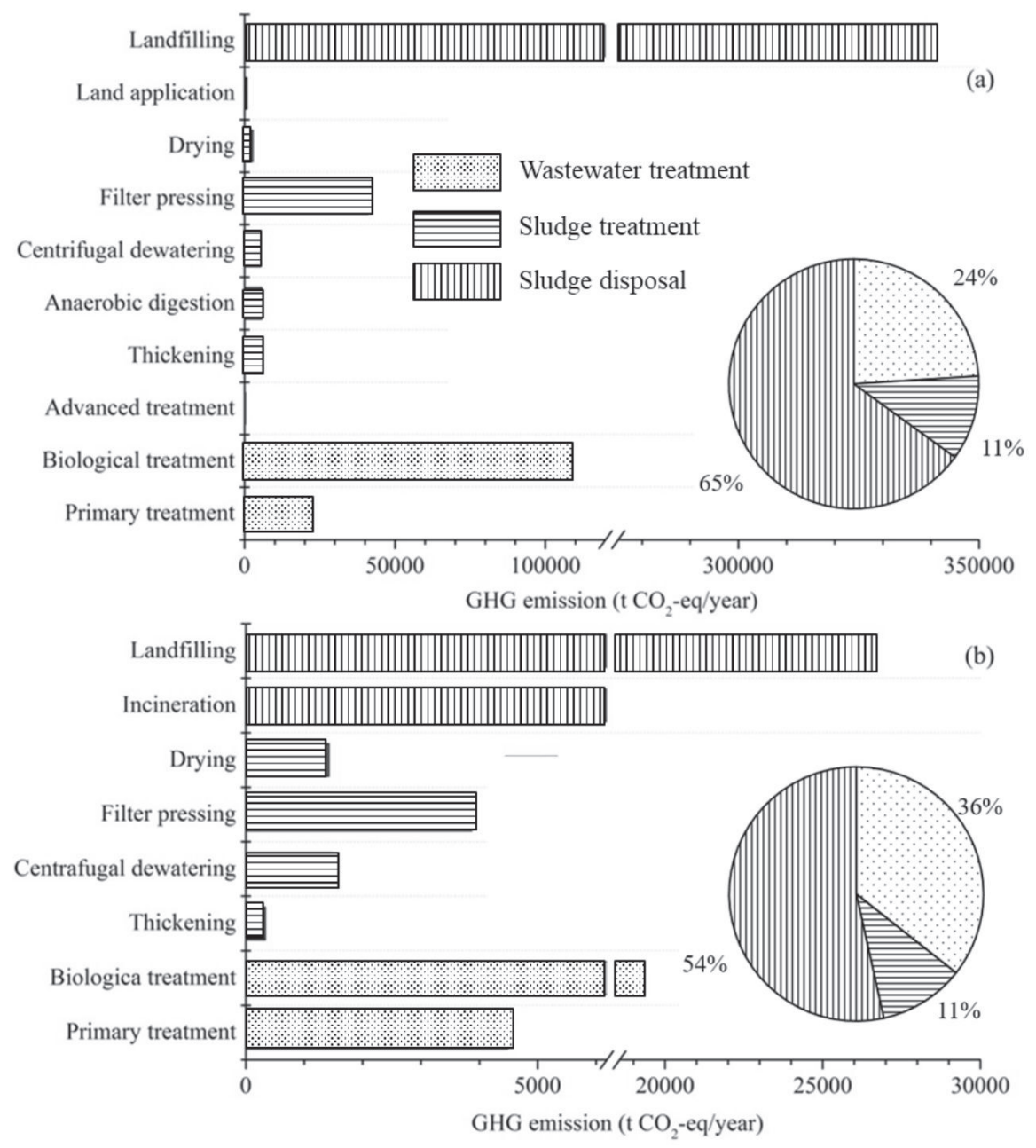

Fig. 2. Distribution of GHG emissions from A-WWTP a) and B-WWTP b). 
Table 2. GHG emissions of different sewage sludge management routes.

\begin{tabular}{|c|c|c|c|c|c|}
\hline \multirow{2}{*}{$\begin{array}{c}\text { Treatment and } \\
\text { disposal }\end{array}$} & \multicolumn{2}{|c|}{$\begin{array}{c}\text { Indirect emission } \\
\left(\mathrm{kg} \mathrm{CO}_{2} \text {-eq/t DS }\right)\end{array}$} & $\begin{array}{c}\text { Direct emission } \\
\left(\mathrm{kg} \mathrm{CO}_{2} \text {-eq/t DS }\right)\end{array}$ & $\begin{array}{c}\text { Avoided emission } \\
\left(\mathrm{kg} \mathrm{CO}_{2} \text {-eq/t DS }\right)\end{array}$ & $\begin{array}{c}\text { Total } \\
(\mathrm{kg} \mathrm{CO} \text {-eq/t DS })\end{array}$ \\
\cline { 2 - 5 } & Electricity & Chemical & 259.7 & -134 & 759.2 \\
\hline R1 & 352.1 & 281.4 & 79.2 & 0 & 1458 \\
\hline R2 & 665 & 714.3 & 3755 & 0 & 4322 \\
\hline
\end{tabular}

emissions from wastewater treatment, sludge treatment and sludge disposal is remarkably different in two WWTPs.

As a whole, the sludge treatment and disposal contribute 76\% (A-WWTP) and 65\% (B-WWTP) of the total GHG emissions, respectively. In light of the tremendous sludge production and unclear sludge disposal policy in China, the GHG emission performance of different sludge treatment and disposal routes should be compared. Meanwhile, there is a huge GHG reduction potential in sludge treatment and disposal because of biogas utilization and energy recovery. Thus, the treatment and disposal of sludge would be the important part for reduction of GHG emissions.

\section{Comparison of the GHG Emission from Different Sludge Treatment and Disposal Routes}

Based on processes of the case WWTPs studied in eastern China, three sludge treatment and disposal routes are selected to analyze the GHG emission, including: thickening + anaerobic digestion + centrifugal dewatering + drying + land application (R1); thickening + centrifugal dewatering + drying + incineration (R2); thickening + filter pressing + landfilling (R3). The total GHG emissions of different sewage sludge management routes are tabulated in Table 2. Sludge landfilling produces the largest amount of GHG emission (4322 kg $\mathrm{CO}_{2}$-eq/t DS), followed by incineration (3124 kg $\mathrm{CO}_{2}$-eq/t DS), and land application (489 $\mathrm{kg} \mathrm{CO}$-eq/t DS). For R1, the total GHG emissions are mainly from electricity consumption and direct emissions. For R2, the GHG emissions are mainly emitted from chemical usage, and direct emission is found to be the largest emission for R3. R1 produces avoided emissions of -134 kg CO 2 -eq/t DS. However, R2 and R3 produce no avoided emission because of technological limit and improper management in this case.

The proportions of GHG emission from each treatment unit in three sludge management routes are shown in Fig. 3. In R1, the total GHG emissions are mainly from sludge drying unit. Incineration unit is the predominant contributor accounting for $78 \%$ of total GHG emission in R2 due to a large amount of auxiliary fuels (coal) consumption. As the largest

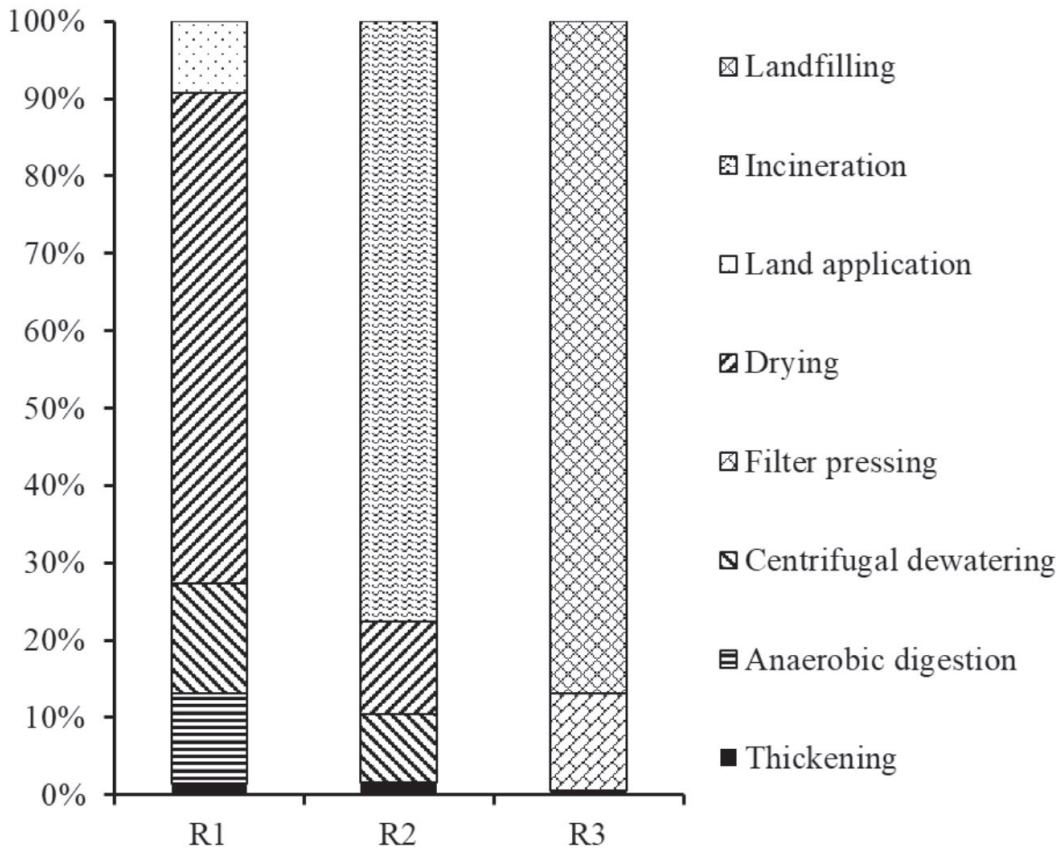

Fig. 3. The proportion of GHG emission from each unit in three sludge treatment and disposal routes. 
GHG emission unit, sludge landfilling accounts for $87 \%$ of total GHG emission in R3. Thus, proper techniques and carbon reduction strategies should be carried out in sludge drying, incineration and landfilling units.

\section{Analysis of the Potential Avoided GHG Emission in R1, R2 and R3}

\section{Sludge Anaerobic Digestion}

If captured and managed efficiently, anaerobic digestion technology could yield substantial energy in the form of biogas [26]. For the case study of A-WWTP (Fig. 4), the generated biogas was firstly utilized for temperature maintenance of digester, the rest of that was for heat consumption by sludge drying. According to the field survey, the anaerobic digester generated $11 \mathrm{~m}^{3}$ biogas $/ \mathrm{m}^{3}$ sludge, and consumed $5 \mathrm{~m}^{3}$ biogas. The remaining $6 \mathrm{~m}^{3}$ biogas was used for sludge drying unit. However, the heat generated by $6 \mathrm{~m}^{3}$ biogas was not sufficient for sludge drying, and auxiliary coal (125 MJ) was added to sludge drying unit. Biogas production at Chinese WWTPs ranges from 4 to $14 \mathrm{~m}^{3}$ biogas $/ \mathrm{m}^{3}$ sludge $($ HRT $=20 \mathrm{~d})$, whereas biogas production at the US WWTPs ranges from 18 to $22 \mathrm{~m}^{3}$ biogas $/ \mathrm{m}^{3}$ sludge [27]. The sludge drying unit can utilize more biogas if biogas production rate was improved through hydrolysis and other technologies. Biogas production rate at $16.5 \mathrm{~m}^{3}$ biogas $/ \mathrm{m}^{3}$ sludge just supply enough heat for sludge drying. The excess biogas can be used for combined heat and power generation (CHP), which is regarded as avoided GHG emission in this study. The avoided GHG emission from CHP is $131 \mathrm{~kg} \mathrm{CO}$ at the biogas production rate of $22 \mathrm{~m}^{3}$ biogas $/ \mathrm{m}^{3}$ sludge.

\section{Sludge Incineration}

For the case A-WWTP, sludge drying decreased the moisture content of sludge from $80 \%$ to $10 \%$. Water evaporation of sludge in drying unit was 778 $\mathrm{kg} / \mathrm{t}$ sludge. The heat required to evaporate $1 \mathrm{~kg}$ water from sludge was about $3 \mathrm{MJ}$. Thus, in total, heat consumption is $2334 \mathrm{MJ}$ per ton sludge for drying. In this case, auxiliary coal $(70.4 \mathrm{~kg})$ was added to the furnace to enhance the heating value. The coal and sludge generated $3771 \mathrm{MJ}$ of energy when incinerated in the furnace. Many European countries recover the excess heat produced by municipal solid waste incineration. The substitutions of electricity generated in European countries are higher than Chinese cities due to the greater efficiency of electricity recovery in Europe (30\%) than in China (17\%) (28). If the energy recovery strategy in case WWTP could be improved from electricity recovery efficiency of $17 \%$ to $30 \%$, the avoided GHG emission would change from $55 \mathrm{~kg}$ to

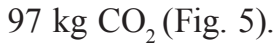
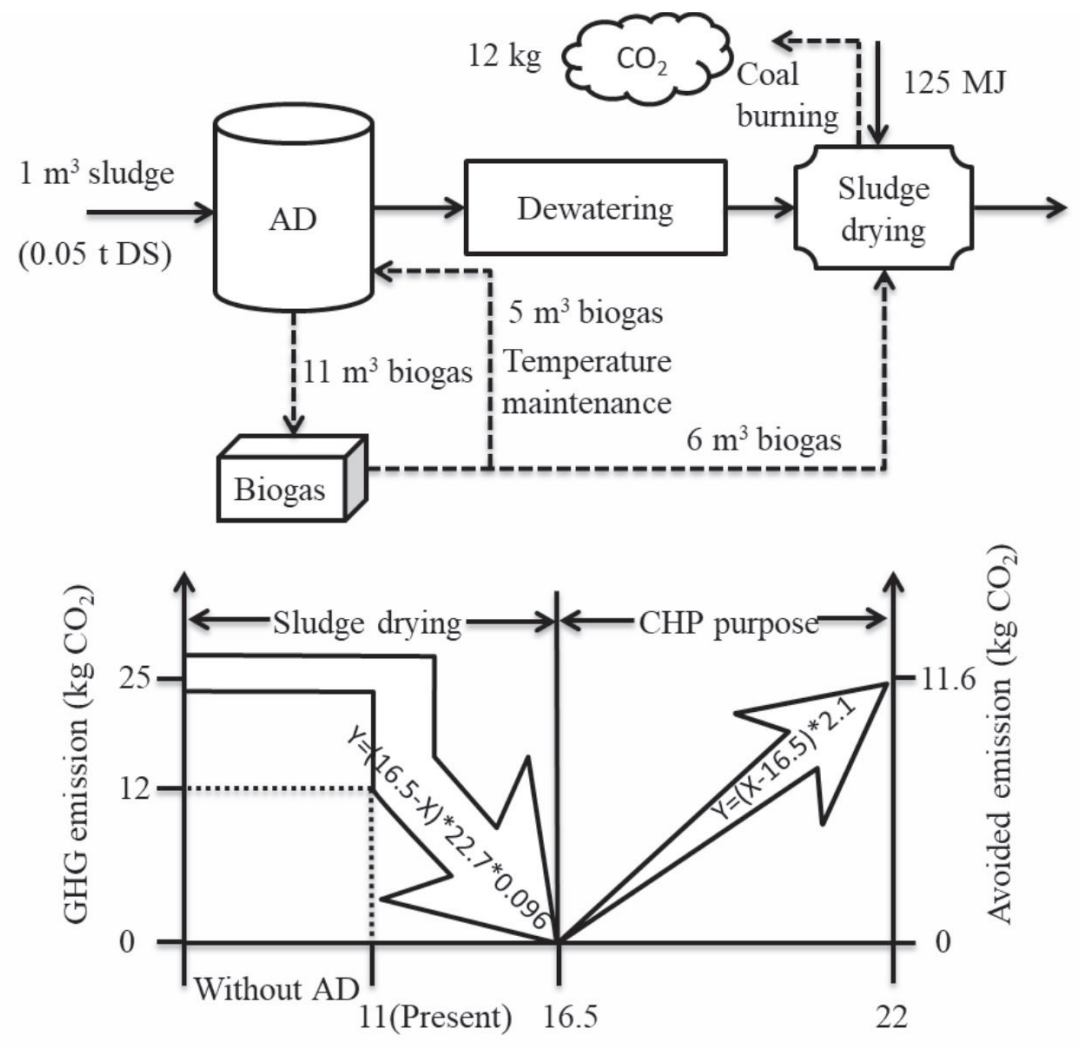

Biogas production $\left(\mathrm{m}^{3}\right.$ biogas $/ \mathrm{m}^{3}$ sludge)

Fig. 4. Avoided emission from anaerobic digestion. 


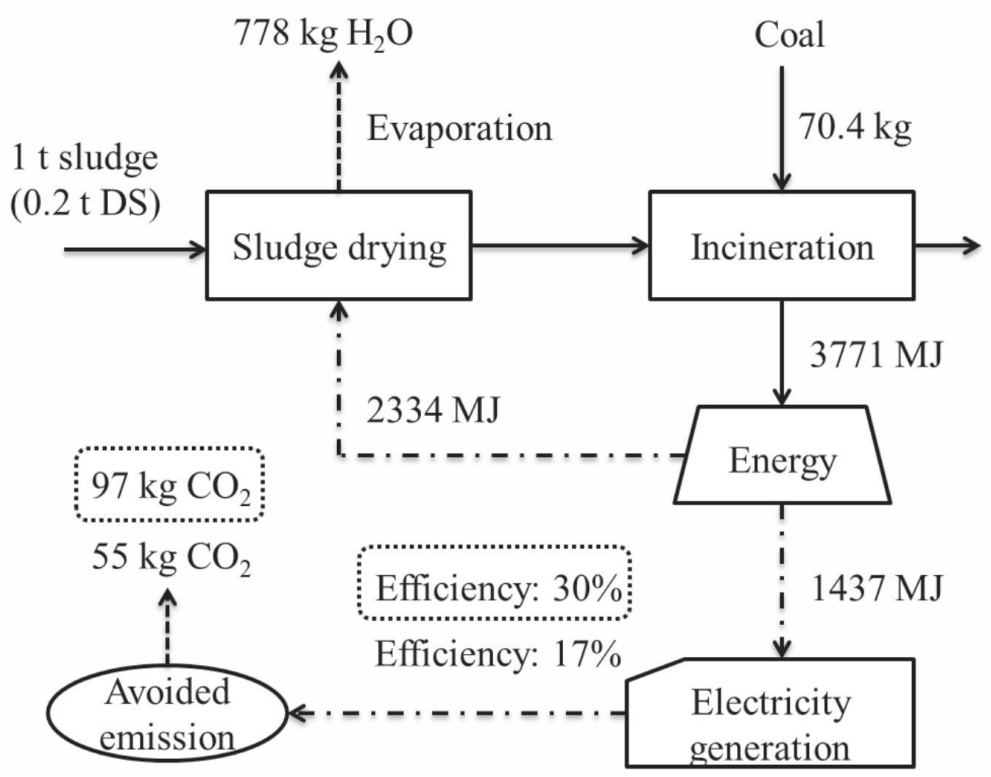

Fig. 5. Avoided emission from sludge incineration.

\section{Sludge Landfilling}

Unlike the situation in developed countries, there is a considerable amount of sewage sludge in China disposed to landfills that are not equipped with landfill gas (LFG) extraction systems (29). As more regulated sanitary landfills are constructed and put into operation, extraction and treatment of LFG may become more important in the management of landfill sites in China. If LFG was collected effectively and utilized for energy recovery (usually for heat and electricity production), the avoided GHG emissions from landfill gas utilization would be calculated. In this study we assume, when CHP is used in the landfill site, with LFG collection efficiencies of $50 \%$ (the value of China) and $75 \%$ (the default value by U.S. EPA, 2009), the avoided GHG emissions under the two efficiencies are 343 and $514 \mathrm{~kg}$ $\mathrm{CO}_{2} / \mathrm{t} \mathrm{DS}$, respectively.

\section{Impacts of Energy Recovery Strategy on GHG}

Emission Reduction of Sludge Disposal Routes

The GHG emission from sludge treatment and disposal could be reduced on the basis of the above analysis. This study set up energy recovery strategies for reducing GHG emission from R1, R2 and R3 in three ways: improving biogas production rate, electricity recovery efficiency and LFG collection efficiency. Strategy A is defined as: biogas production rate of $16.5 \%$ (R1), electricity recovery rate of $17 \%$

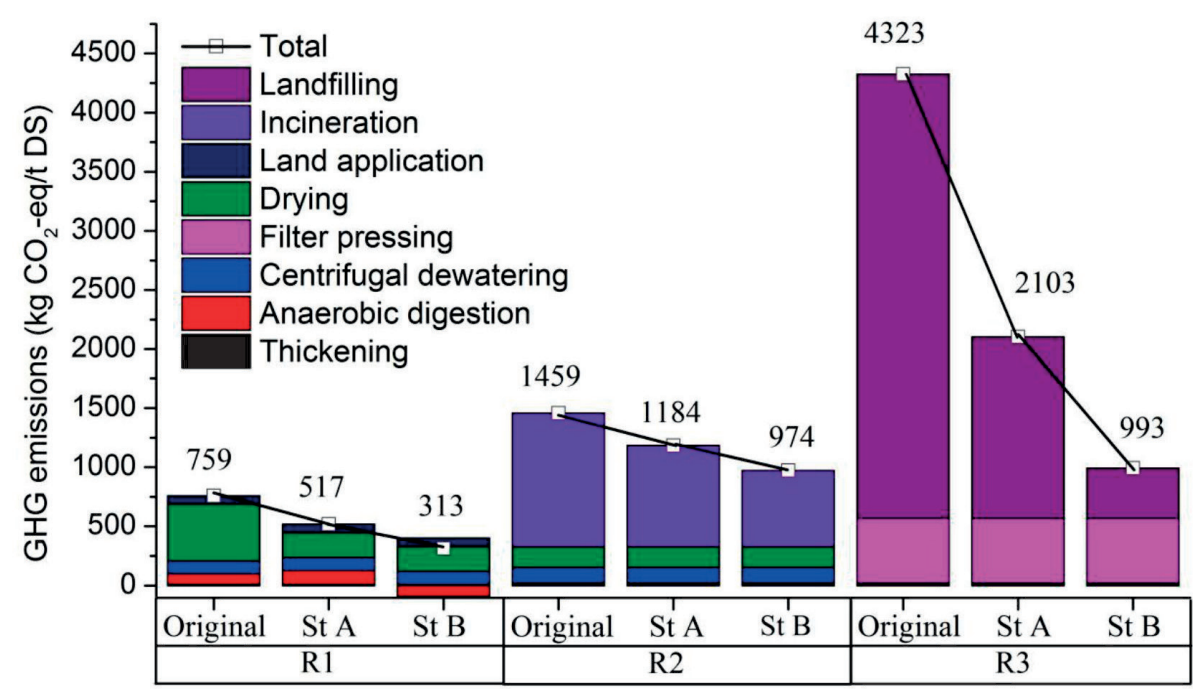

Fig. 6. The before and after optimized GHG emissions from R1, R2 and R3. "Original" refers to original situation in the case study. "St" refers to Strategy. 
(R2), and LFG collection efficiency of $50 \%$ (R3). Strategy B is defined as: biogas production rate of $80 \%$ (R1), electricity recovery efficiency of $30 \%$ (R2), and LFG collectioThe results of GHG emissions from R1, R2 and R3 before and after optimization are presented in Fig. 6. The proposed strategy A and B significantly reduced GHG emissions from R1, R2 and R3. Among them, R3 had the largest reduction rate of 51\% (Strategy A) and $77 \%$ (Strategy B) because the LFG extraction system brought double GHG emission reduction effects. The LFG collection and utilization not only reduced the direct methane emission to atmosphere, but also created an offset emission as an energy source. The GHG emission from R2 with strategy B is $993 \mathrm{~kg}$ $\mathrm{CO}_{2}$-eq/t DS, which is nearly the same as $\mathrm{R} 2$ with strategy B (974 kg CO -eq/t DS). This means that sludge landfilling and incineration would have the same global warming potential impact after optimization. For R1, sludge treatment contributed the most to GHG emission because of sludge drying. However, sludge anaerobic digestion with improved biogas production reduced GHG emission from sludge drying effectively, and offered negative GHG emission with strategy B. Overall, R1 had the smallest GHG emission, followed by R2 and R3. Energy recovery strategies had a small reduction of GHG emission from R1 and R2. However, a significant GHG reduction was achieved in $\mathrm{R} 3$ due to the double GHG emission reduction effects.

\section{Outlooks on Sludge Management}

Sludge management is a common issue faced by different countries worldwide. As the biggest developing country, China's solution to reduce GHG emissions from sludge treatment and disposal can provide some advices for other developing countries. Anaerobic digestion has been recognized as an effectively technology to reduce GHG emission, as well as the thermal energy recovery from incineration and landfilling gas utilization. The agricultural utilization of sludge can be promoted in the regions where the sludge contains an acceptable level of pollutants (eg. heavy metals, persistent organic pollutants). The percentage of EU-15 countries adopting landfill disposal decreased from $33 \%$ to $15 \%$ significantly between 1992 and 2005(30). The percentage of sludge landfilling will be smaller in economically developed areas in China. However, incineration is the preferable disposal method because this technology has less land occupation and GHG emission. The common future direction is to minimize landfill disposal of sludge and to utilize sludge as a source of energy.

\section{Conclusion}

The direct, indirect and avoided GHG emission from case WWTPs were calculated in this study. As a whole, sludge management was an important source of GHG emission for the hybrid WWTPs. For the two case WWTPs, landfilling unit was the main $\mathrm{CO}_{2}$ emissions source. Large-scale WWTPs in China usually have three typical sludge disposal routes which are land application (R1), incineration (R2) and landfilling (R3). Anaerobic digestion, incineration and landfilling unit were considered the energy sources for generating avoided GHG emission. Energy recovery strategies such as improving biogas production rate, electricity recovery efficiency and LFG collection efficiency reduced significantly GHG emission from three routes. The future direction for sludge management policy to reduce GHG emission in China would be utilizing sludge as a source of energy, including the use of incineration for heat recovery and reduction of landfill disposal loads, as well as the adoption of anaerobic digestion technology to recover energy from biogas.

\section{Acknowledgements}

The authors thank the National Key Science \& Technology Project of China for finical support of this study.

\section{Conflict of Interest}

The authors declare no conflict of interest.

\section{References}

1. DELRE A., MØNSTER J., SCHEUTZ C. Greenhouse gas emission quantification from wastewater treatment plants, using a tracer gas dispersion method. Science of the Total Environment, 605, 258, 2017.

2. KOUTSOU O.P., GATIDOU G., STASINAKIS A.S. Domestic wastewater management in Greece: greenhouse gas emissions estimation at country scale. Journal of Cleaner Production, 188, 851-859, 2018.

3. BARBU M., VILANOVA R., MENESES M., SANTIN I. On the evaluation of the global impact of control strategies applied to wastewater treatment plants. Journal of Cleaner Production, 149, 396, 2017.

4. YERUSHALMI L., ASHRAFI O., HAGHIGHAT F. Reductions in greenhouse gas (GHG) generation and energy consumption in wastewater treatment plants. Water science and technology, 67 (5), 1159, 2013.

5. NGUYEN T.K.L., NGO H.H., GUO W., CHANG S.W., NGUYEN D.D., NGHIEM L.D., LIU Y., NI B., HAI F.I. Insight into greenhouse gases emissions from the two popular treatment technologies in municipal wastewater treatment processes. Science of the Total Environment, 671, 1302, 2019.

6. GUSTAVSSON D.J.I., TUMLIN S. Carbon footprints of Scandinavian wastewater treatment plants. Water Science and Technology, 68 (4), 887, 2013.

7. LIU B., WEI Q., ZHANG B., BI J. Life cycle GHG emissions of sewage sludge treatment and disposal options in Tai Lake Watershed, China. Science of the Total Environment, 447, 361, 2013. 
8. YOSHIDA H., MØNSTER J., SCHEUTZ C. Plantintegrated measurement of greenhouse gas emissions from a municipal wastewater treatment plant. Water research, 61, 108, 2014.

9. KYUNG D., KIM M., CHANG J., LEE W. Estimation of greenhouse gas emissions from a hybrid wastewater treatment plant. Journal of Cleaner Production, 95, 117, 2015.

10. ZENG S., CHEN X., DONG X., LIU Y. Efficiency assessment of urban wastewater treatment plants in China: Considering greenhouse gas emissions. Resources, Conservation and Recycling, 120, 157, 2017.

11. YANG G., ZHANG G., WANG H. Current state of sludge production, management, treatment and disposal in China. Water Research, 78, 60, 2015.

12. HARRIS E., ZEYER K., KEGEL R., MÜLLER B., EMMENEGGER L., MOHN J. Nitrous oxide and methane emissions and nitrous oxide isotopic composition from waste incineration in Switzerland. Waste Management, 35, 135, 2015.

13. BROWN S., BEECHER N., CARPENTER A. Calculator tool for determining greenhouse gas emissions for biosolids processing and end use. Environmental Science \& Technology, 44 (24), 9509, 2010.

14. MA X.W., WENG H.X., SU M.H., PAN L. Drying sewage sludge using flue gas from power plants in China. Environmental Earth Sciences, 65 (6), 1841, 2012.

15. DE VRIEZE J., SMET D., KLOK J., COLSEN J., ANGENENT L.T., VLAEMINCK S.E. Thermophilic sludge digestion improves energy balance and nutrient recovery potential in full-scale municipal wastewater treatment plants. Bioresource Technology, 218, 1237, 2016.

16. IPCC. IN: EGGLESTON H.S., BUENDIA L., MIWA K., NGARA T., TANABE K. (Eds.), 2006 Guidelines for National Greenhouse Gas Inventories. Prepared by the National Greenhouse Gas Inventories Programme. IGES, Japan, 2006.

17. CZEPIEL P., CRILL P., HARRISS R. Nitrous oxide emissions from municipal wastewater treatment. Environmental Science \& Technology, 29 (9), 2352, 1995.

18. UNFCCC. Methodological Tool "Project and leakage emissions from anaerobic digesters" (Version 01.0.0), 2012.

19. National Development and Reform Commission (NDRC). Guidelines for provincial greenhouse gas inventories. Beijing, China, 2011.

20. PARK S., CHOI J.H., PARK J. The estimation of $\mathrm{N}_{2} \mathrm{O}$ emissions from municipal solid waste incineration facilities: The Korea case. Waste Management, 31 (8), 1765, 2011.
21. National Development and Reform Commission (NDRC). Baseline emission factors for regional power grids in China. Beijing, China, 2016.

22. TRIPATHI M. Life-cycle energy and emissions for municipal water and wastewater services: case-studies of treatment plants in US. [Master Thesis]. Michigan: University of Michigan, 2007.

23. KAPARAJU P., RINTALA J. Mitigation of greenhouse gas emissions by adopting anaerobic digestion technology on dairy, sow and pig farms in Finland. Renewable Energy, 36 (1), 31, 2011.

24. HOSPIDO A., CARBALLA M., MOREIRA M., OMIL F., LEMA J.M., FEIJOO G. Environmental assessment of anaerobically digested sludge reuse in agriculture: potential impacts of emerging micropollutants. Water Research, 44 (10), 3225, 2010

25. NIU D.J., HUANG H., DAI X.H., ZHAO Y.C. Greenhouse gases emissions accounting for typical sewage sludge digestion with energy utilization and residue land application in China. Waste Management, 33 (1), 123, 2013.

26. KOR-BICAKCI G., UBAY-COKGOR E., ESKICIOGLU C. Effect of dewatered sludge microwave pretreatment temperature and duration on net energy generation and biosolids quality from anaerobic digestion. Energy, 168, $782,2019$.

27. SHEN Y., LINVILLE J.L., URGUN-DEMIRTAS M., MINTZ M.M., SNYDER S.W. An overview of biogas production and utilization at full-scale wastewater treatment plants (WWTPs) in the United States: challenges and opportunities towards energy-neutral WWTPs. Renewable and Sustainable Energy Reviews, 50, 346, 2015.

28. YANG N., ZHANG H., CHEN M., SHAO L.M., HE P.J. Greenhouse gas emissions from MSW incineration in China: Impacts of waste characteristics and energy recovery. Waste Management, 32 (12), 2552, 2012.

29. YANG N., ZHANG H., SHAO L.M., LÜ F., HE P.J. Greenhouse gas emissions during MSW landfilling in China: Influence of waste characteristics and LFG treatment measures. Journal of Environmental Management, 129, 510, 2013.

30. KELESSIDIS A., STASINAKIS A.S. Comparative study of the methods used for treatment and final disposal of sewage sludge in European countries. Waste Management, 32 (6), 1186, 2012. 